\title{
Experience in using information technologies in teaching foreign literature
}

\author{
Anna Kaneeva ${ }^{*}, 1$, Sofia Minasyan ${ }^{1}$, and Tatyana Bagdasaryan ${ }^{1}$ \\ ${ }^{1}$ Don State Technical University, Gagarina, 1, 344000 Rostov-on-Don, Russia
}

\begin{abstract}
The article deals with the features of using information technologies in teaching modern foreign literature to students of various training areas and specialties including future personnel of the agroindustrial complex. The timeliness of this strategy is due to the fact that in the twentieth century there was a general tendency of Western art to rethink traditional approaches and norms in creativity. Russian youth, brought up mostly on the traditions of critical realism in Russian literature, is not always ready for an adequate perception of the latest techniques of the author's mask, the grotesque principle of modeling artistic reality. It is also not ready for the grotesque principle of modeling artistic reality, and stage play in works, finally, the shock-grotesque fullness, in some cases leading to conflicts up to the confrontation of civilizations (the events surrounding the French satirical weekly Charlie Hebdo ("Charlie's Weekly"). This problem is important today because it is aimed at eliminating this gap in education. The article presents personal experience of the authors in the priorities of the choice of teaching technologies in this discipline. The effectiveness of using social networks to discuss literary works is shown.
\end{abstract}

\section{Introduction}

Informatization of education significantly expands the opportunities to achieve a deep and broad mastery of the material by students. It increases their communication skills and academic mobility [1-6].

The use of information technologies in the educational process has shown its effectiveness in teaching modern foreign literature to students whose training area is Service and tourism.

Before talking about the innovative methods that are introduced into the educational process due to the Informatization of society and the widespread use of information technologies [7], we would like to express an opinion about the need to introduce almost all areas of training and specialties of higher education into the curriculum as an elective or optional discipline "History of foreign literature of the XX-XXI century".

\footnotetext{
*Corresponding author : m_anna7@mail.ru
} 
The necessity is dictated by the fact that students on the basis of secondary education have knowledge of Russian literature, which plays an important role in molding personality in the line of humanism and high values.

Meanwhile, there is a break in the foreign culture and literature of the twentieth century with the traditions of previous centuries. Moreover, it is clearly visible in the twentieth century. That is why the peculiarities of development in the foreign literature of the twentieth century in the context of the history of world civilization in connection with the ideological, political and sociological trends of the era are extremely relevant today.

This will help to overcome communication barriers with foreign partners in the course of their future professional activities, solve problems of mental interaction, and improve the overall cultural level of the student.

\section{Materials and method}

This article discusses the information technologies used by the authors of the article when teaching the course "History of modern foreign literature" in the following aspects:

1) what technologies were used;

2) which of them showed the greatest effectiveness.

The reference to the course "History of modern foreign literature (XX-XXI centuries)" as an example is due to the fact that it can be taught to students of various training areas in their native language.

This practice is applied at the Don State Technical University when preparing bachelors in the direction of "Service and tourism".

The discipline should include the main areas of literature of the XX century - realism, modernism, postmodernism. The main literary trends and schools of this period such as for example: literature of the "lost generation", avant-garde trends, existentialism, "new novel", non-traditional drama, "magic realism", etc., indicate extreme length, the need to learn and read not only the texts of literary works, but also literary and historical sources.

The use of information technology training creates new opportunities to transfer the knowledge, which is specified in the following main stages of mastering the material.

The first stage is to introduce students to the most prominent personalities of each literary field. During the lectures, the information is given that includes socio-historical and philosophical prerequisites for the formation of the features of this literary direction. Students deal with its general historical and literary characteristics,

the main literary trends, as well as literary categories significant for this direction, brief information about representatives of literary schools, a list of reference literary texts and their adaptations.

Having prepared the required socio-psychological platform for direct acquaintance with the work of writers, we can proceed to the second stage.

The second stage includes students' independent study with texts. Here the important role plays the access to the global Internet network. Students must have it not only from their home computer, but also directly from the educational institution: in special computer classes and libraries.

This allows students to access electronic libraries, encyclopedias, dictionaries, biographical material, as well as interactive databases, which provide not only full-text copies, but also adapted texts, and to choose the most interesting works of a particular author for a full acquaintance with his work.

Thus, the student chooses a specific work from the list of reference works of art determined by the lecturer. Certainly, it does not exclude reading the compulsory literature provided by the program. It should be emphasized that the structure of electronic libraries 
includes not only electronic versions of literary works, but also critical, art history, memoir and scientific literature.

Students are focused on mastering the technology of searching for documents in an electronic library and creating their own electronic library.

Currently, there are various software products, which are widely represented on the market of educational materials. Working with additional sources using the Internet contributes to the formation of the student's communicative culture [8].

The third stage should be associated with practical training in the discipline. Here the interactivity of learning is provided by a competent selection of innovative technical devices in education, such as interactive whiteboards, movies, audio and video media.

The textbook [9] contains a list of recommended feature films that are adaptations of the works studied and biographies of the writers. Co-watching creates the effect of participation, allowing the teacher to use a freeze-frame to fix students' attention on such specific features of latest literature as the use of grotesque forms, dystopia, absurdity, allusions, pastiche and other means, noting their intertextual significance in the intention of the creators of a literary work and film to involve the recipient in the game with the author.

This is a significant pursuit of students to decode the meanings encoded in the works. This method, of course, generates a genuine interest of students in the study of literature in the game context, and as a result, to read the original work. It should be noted that in the process of discussing the work, it is important to use hypertext technology, which is understood as a means of visual explication of intertextual connections with the literary text.

The teacher must have his ther own video-library and catalog of materials containing popular science programs, documentaries and feature films stored on electronic media for constructive use in practical classes.

The next practical lesson can be devoted to monitoring the level of students' development of the material. There are various forms of information technology.

This is a widely used test control, and students' reports using presentations as a tool for commenting and analyzing a literary work.

The use of presentations allows us not only to assess the level of development of an individual student's material, but also to work in parallel to deepen knowledge in the field of literary theory.

As our practical experience has shown, the fourth stage with social networks was the most effective. The stage was held outside of school hours.

The students were offered to exchange their opinions about one of the most interesting works, which was pointed out by the students themselves during the survey. Each student could specify only one work that he liked the most. It should be noted that the authors did not set the goal of conducting a sociological study using quantitative methods. A sample limited to a single group of students cannot claim to be representative. Rather, we can talk about a pilot survey, but not to identify students' literary preferences, but to identify such a literary text that could be used as the basis for a literary discussion, taking into account the interested response to it from students.

\section{Results}

The results of the survey are shown in Table 1 .

Table 1. Students' preference in choosing a literary work

\begin{tabular}{|l|l|l|}
\hline № & $\begin{array}{l}\text { Literary work (author, title), the students are } \\
\text { interested in }\end{array}$ & $\begin{array}{l}\text { Percentage of } \\
\text { students } \\
\text { in the selection of }\end{array}$ \\
\hline
\end{tabular}




\begin{tabular}{|l|l|l|}
\hline & & the work \\
\hline 1 & E. Hemingway "For whom the Bell Tolls" & $8 \%$ \\
\hline 2 & M. Remarque "Three Comrades" & $7 \%$ \\
\hline 3 & J. Joyce "Portrait of the artist as a young man" & $1 \%$ \\
\hline 4 & F. Kafka "The Trial" & $2 \%$ \\
\hline 5 & G. Gesse "Das Glasperlenspiel" & $2 \%$ \\
\hline 6 & T. Mann "Doctor Faustus" & $1 \%$ \\
\hline 7 & F. Scott Fitzgerald "The Great Gatsby" & $2 \%$ \\
\hline 8 & $\begin{array}{l}\text { Louis-Ferdinand CÉLINE "Journey to the End of } \\
\text { the Night: Voyage au bout de la nuit" }\end{array}$ & $1 \%$ \\
\hline 9 & A. Jarry "King Ubu" & $1 \%$ \\
\hline 10 & $\begin{array}{l}\text { B. Vian "L'Écume des jours" ("The Foam of } \\
\text { Days") }\end{array}$ & $53 \%$ \\
\hline 11 & Jean-Paul Charles Aymard Sartre "La Nausée" & $2 \%$ \\
\hline 12 & A. Camus "L'Étranger" & $1 \%$ \\
\hline 13 & G. Bernard Shaw "Pygmalion" & $1 \%$ \\
\hline 14 & Eugène Ionesco "La Cantatrice Chauve" & $1 \%$ \\
\hline 15 & $\begin{array}{l}\text { G. José de la Concordia García Márquez "Cien } \\
\text { años de soledad" }\end{array}$ & $4 \%$ \\
\hline 16 & J. Cortázar "Rayuela" & $1 \%$ \\
\hline 17 & V. Nabokov "Lolita" & $3 \%$ \\
\hline 18 & John Robert Fowles The Magus" & $3 \%$ \\
\hline 19 & J. D." Salinger "The Catcher in the Rye" & $5 \%$ \\
\hline 20 & Kurt Vonnegut "Slaughterhouse-Five" & $1 \%$ \\
\hline
\end{tabular}

Boris Vian's novel "The Foam of Days" was chosen. The teacher also became a participant in this event, gaining access to the social networks of his students. The result exceeded all expectations.

The talk was about the form of the grotesque representation of reality in the novel, about the understanding of the fantastic, and about the allusions used by the author. The formula of life expressed by the main character was discussed ("I am not interested in the happiness of all people, but in the happiness of each individual"), and the reasons for the impossibility of the idyllic world of the main characters.

Boris Vian's novel "Foam of Days" was chosen, which can be considered as a fairly predictable result. It is no secret that the novel "Foam of Days" is popular among young people. According to the characterization of G. Kosikov, it should be considered "a hymn of youth, opposing adult life" [10]. Many students read the novel, and therefore the interest in discussing it was sincere.

At the same time, starting from the attention shown to the work, it is good to use this work as a base form. It can be some encyclopedia to develop a specific realizing such literary device as grotesque.

Reinforced by a fantastic foundation, the novel presents a whole arsenal of such literary techniques, ranging from the anomalies of living images, objects and nature, the materialization of feelings and thoughts to the use of the effect of deceived expectations, space-time distortions, ambivalence.

Of great importance is the fact that "The Foam of Days", as well as other novels by Vian, is a pastiche, a self-parody, an allusion to various literary trends.

Vian's literary identity is characterized by his unique ability to mix different directions in one text. 
The intertextual basis of the novel promotes cultural dialogue with various literary and philosophical trends of modern times.

Thus, joining in the play, dictated by the author of the novel, the recipient gets a deeper understanding of the literary process. The features were given in previous phases of teaching. The teacher was also a participant in this event as he had access to the social networks of his students. The results were outstanding.

The discussion was about grotesque representation of reality in the novel, about the understanding of the fantastic and about the expressive means used by the author.

The formula of life expressed by the main character ("I am not interested in the happiness of all people, but the happiness of each individual") was discussed [11], and the reasons for the impossibility of the idyllic world of the main characters. Many comments were devoted to the philosophy of existentialism and the character of the novel by Jean-Sol Partre.

\section{Discussion}

A special place in the discussion was occupied by the question of the engagement of literature and the media. The problem was raised by one of the students about the the meeting of the philosophical circle under the leadership of the servant Colin Nicolas in the novel.

The students themselves gave explanations to the chat participant who had time to find out about Vian's disbiased position, about his opposition to Jean Paul Sartre [12] and the existentialists with their characterization of the XX century as "the era of biased literature".

This discussion is particularly relevant in the current situation. It is important because of the events related to the closure of US President Trump's access to social media.

It can be concluded that thanks to the study of foreign literature of the XX century, students already have a balanced socio-political basis for their views and actions.

At first, personal digital assistant devices allowed the students to be connected and available regardless of their location. They went to the social network for a week. Their discussion lasted for a week till the next lesson.

Therefore, at the next practical lesson, the teacher has the opportunity to analyze the kaleidoscope of opinions, to explicate their coincidences in a number of aspects and at the same time the teacher focuses attention on differences, coloured by the peculiarities of individual preferences.

Interest in the future fate of the Knee was revealed. This served as an impetus for further discussion of the novel work of Boris Vian, as the teacher pointed out that it has a biographical and genetic orientation.

The characters of previously written novels pass into his next novels in other images. There was an addition recommendation for the students -- to get acquainted with the literary works of this article [13-15].

This was the result of reading the novels "Autumn in Beijing", "Red Grass" and "Sertseder". The result was reflected in the next week's discussion via social networks with a deeper understanding of the meaning of intertexts and hypertexts in these novels.

Undoubtedly, Vian's work can be considered as a forerunner of postmodernism. However, there is one important clarification. The writer's entire work is characterized by the desire to create a wide field for criticism of public and social institutions, but all his works contain a deep philosophical layer of high ideals and aspirations.

We can surely add that his barely discernible rebellious voice is fighting for the triumph of justice and human dignity, which clearly dissonates with the postmodernists' proclaimed attitude to the millennia - old ideals of human civilization-Truth, Goodness and Beauty. 
The students were passionate about reading the work. In an attempt to maintain this interest, a topic for discussion was proposed - Boris Vian's attitude to the Second World War.

It should be noted that European culture responded loudly to the events of the First World War, as evidenced by the literature of the "lost generation" (E. Hemingway, R. Aldington, E. M. Remarque, etc.) and revolutionary literature (Henri Barbusse, R. Lefebvre, P. Vaillant-Couturier). As for the Second World War, there is no such vivid literary response. Perhaps this is due to the fact that the governments of European countries almost went to cooperate with Hitler's Germany.

It should be noted the exposure and condemnation of the Nazi past in the novels of G. Bell, G. Grass and East German writers.

Boris Vian maintains his position and does not explicitly express his attitude, but as a master of encoding and intertextual encryption he carries the theme of war through all his novels.

Most clearly, it can be seen in the early novel of the writer "of Centipedes, and plankton" [16]. The students were offered to read this work and also to get acquainted with his other works $[17,18]$. Through the expressive means grotesque that can be traced throughout the novel, Vian's sorrowful and wounded attitude towards the collaborationist position of the motherland clearly breaks through.

Therefore, nothing saves Vian as a citizen and patriot from ridiculing and uncompromising condemnation of the war. Almost all of Vian's texts have implicit rebellious tendencies [19].

For the purpose of patriotic education and for comparison of the grotesque techniques used, the following attempt was taken. The Russian novel by famous writer Viktor Pelevin "Omon Ra" was discussed.

The first thing that deserves special attention is the complete ignorance and nonacquaintance of young people about the feat of the Soviet Union hero - Alexey Maresyev. Unfortunately, most students often hear this name for the first time. Viktor Pelevin's work helps, as the flight school mentioned in the novel is named after him.

After that, the students get acquainted with his personality and biographical and historical events associated with the name of the hero via the Internet. This allows the students to formalize their personal attitude not only to the individual, and the work, but also to the historical era.

\section{Conclusion}

The practice of discussing literary works using social networks has shown its undeniable effectiveness and can be recommended for extensive use in the educational process.

It is necessary to highlight the following advantages of using social networks to communicate with students in the teaching the course "History of Modern foreign Literature":

1.The discussion of a popular work among young people, chosen as a starting point for the analysis, stimulates interest in reading the works by this author and other writers across the entire spectrum of discussed topics, literary forms and means that are explicated in the discussion.

2.Increasing interest in reading works by foreign authors is in line with the awakening of students' desire for self-education, as they believe they have sufficient knowledge of Russian literature.

3.The twentieth century demonstrates the gap between the literature of the Soviet period and foreign literature. The students are introduced to literary techniques that were widely used in foreign literature of the twentieth century, such as" stream of consciousness "(J. 
Joyce, V. Wolf, etc.) or the principle of "stunning image", "automatic writing" (Surrealists), which helps them better understand the manifestations of modern foreign and domestic literature and culture.

4.It is natural to take steps towards a wider acquaintance of young people with Russian literary works. As an example, let us turn to the discussion of grotesque techniques. Techniques and means of grotesque depiction of reality contribute to the emergence of interest in such authors of the twentieth century as D. Harms or L. Andreev. These authors are usually not included in the compulsory school curriculum. The discussion of $\mathrm{M}$. Bulgakov's novel "The Master and Margarita" can be included here.

5.Use of social networks, in particular vk.com, allows students to get acquainted with thematic communities that regularly publish information of a cognitive and developmental nature about literary trends and writers of the XX-XXI centuries. ("Librarium", "Anthology of book aesthetics", "XX century. Otdel kadrov" (Human resources Department), as well as motivate them to join these communities, which leads to a constant increase in cultural level after the end of the course.

All of the above activities are developing the desire to read literary works, which could help the Russian people return to the status of "the most reading people in the world". During the training process, there is a close interaction between the teacher and students. The teacher acts as a moderator in this interaction.

Thus, the use of social networks is one of the methods for developing a student's own view on modern contradictions of a socio-political and spiritual nature. This is the technology for developing students' creativity.

\section{References}

1. A. Dakhin, The Moscow University Bulletin. Series 20. Pedagogical Education 3, 21$28(2016)$

2. V. Traynev, Anatoly Goloborodov, Invfomation and Telecommunication Technologies 28, 37-43 (2015)

3. I. Zakharova, Invfomation Technologies in the Edication, 208 (Moscow, 2013)

4. I. Semenova, Bulletin of Moscow state regional university. Series "Pedagogics" 1, 135-146 (2016) doi: 10.18384/2310-7219-2016-1-135-146

5. G. Bulman, R. W. Fairlie, Technology and Education: Computers, Software, and the Internet, National Bureau of Economic Research 1050, 02138, 67 (Massachusetts Avenue Cambridge, MA, 2016)

6. Dr. N. Dabas, International Journal of Engineering and Techniques, Series 4, 1, 570574 (Jan -Feb 2018)

7. S. Ahmed Saif Abdulmughni, International Journal of English Linguistics, Series 9 2, 412-428 (2019) doi: 10.5539/ijel.v9n2p412

8. I. Bobrova, E. Trofimov, Invfomation Technologies in the Edication, 195 (Moscow, Flinta, 2019)

9. S. Minasyan, History of foreign literature of the XX century, 88 (Rostov-on-Don, 2016)

10. G. Kosikov, About Boris Vian's prose, http://20v-euro-lit.niv.ru/20v-euro-lit/articlesfranciya/kosikov-o-proze-borisa-viana.htm (Last accessed 2021/03/21)

11. Boris Vian, The Foam of Days, 197-356 (Rostov-on-Don, Feniks, 1999)

12. Jean-Paul Sartre, What Is Literature? https://archive.org/details/whatisliterature030271mbp/page/n11/mode/2up (Last accessed 2021/03/21)

13. S. Minasyan, The humanities and socio-economic sciences 5, 77-81 (2012)

14. A. Kaneeva, S. Minasyan, The humanities and social Sciences 4, 91-104 (2016) 
15. B. Vian, Vercoquin and the Plankton/ The Foam of Days, 79-196 (Rostov-on-Don, Feniks, 1999)

16. S. Minasyan, Philology: scientific researches 2, 168-178 (2019) doi: 10.7256/24540749.0.0.29401

17. A. Hugill, Pataphysics: a useless guide, 430 (Cambridge, Masschusetts; London, England: The MTT Press, 2012). 